\title{
Knowledge and Attitude of Mothers Regarding Rabies and its Preventive Measure
}

\author{
Noura Gameel Ahmed Elkholy ${ }^{1}$, Hala Mostafa Elhady ${ }^{2}$ and Amina Abd-Elrazek Mahmoud ${ }^{3}$ \\ (1) Nursing Inspector in the Directorate of Health in Qalyubiya Faculty of Nursing, Benha University, \\ (2) Professor of Public Health and Community Medicine, Faculty of Medicine, Benha University and \\ (3) Assistant Professor of Community Health Nursing, Faculty of Nursing, Benha University
}

\begin{abstract}
Background: Rabies is acute viral disease of the nervous system caused by Rhabdo viridae Lyssa virus present in saliva of rabid animals. The aim of this study was to assess knowledge and attitude of mothers regarding rabies and its preventive measures. Research design: A descriptive cross sectional study will be conducted in this study. Setting: The study was conducted at Maternal and Child Health Center (B) at Benha City. Sample: Simple random sample was used included 360 mothers. Tools of data collection: A structured interviewing questionnaire was used to assess demographic data of the studied mothers, mothers' knowledge about rabies, and mothers' attitude toward rabies. Results: $41.4 \%$ of the studied mothers aged 40 years and more, $41.7 \%$ of mothers had secondary educational level. $93.1 \%$ of the studied mothers had poor knowledge score. $57.5 \%$ of the studied mothers had indifferent total attitude score. There were a highly statistically significant relations between demographic characteristics of the studied mothers and their age, educational level, occupation and family income and family size $(\mathrm{p}<0.001)$. There were not significant relationship between the studied mothers' attitude and their socio demographic characteristics (age, educational level, occupation, residence, family income and family size) ( $>0.05$ ). Conclusion: There was a highly statistically significant correlation between total knowledge and attitudes of the studied mothers related to rabies $(\mathrm{P}<0.001)$. Recommendations: Health educational program should be developed and implemented for mothers about rabies to educate them with the most current information and attitude about the disease and its preventive measures. Booklets should be available and distributed to all mothers about the disease and health-related practices. All possible forms of mass media such as T.V., Radio, and posters are needed to help in disseminating information about rabies.
\end{abstract}

Key words: Rabies; Knowledge; Mothers; Preventive Measure.

\section{Introduction}

Rabies is one of the oldest recognized infectious diseases, and affects all mammals, usually caused by arhabdo virus, and transmitted to humans by domestic dog bites. Rabies is considered a major public health problem in Egypt. Control and prevention the disease is available through mass $\operatorname{dog}$ vaccination and provision of post-exposure prophylaxis to people exposed to bites by suspect rabid animals. Canine rabies remains a major socioeconomic and public health problem in developing countries, claiming the lives of an estimated 55,000 people each year. Annual incidence of human rabies deaths typically fall between 1 and 6 cases/100,000 


\section{Knowledge and Attitude of Mothers Regarding Rabies and its Preventive Measure}

people in canine rabies endemic areas (Hossain et al., 2018).

Rabies is present in more than 150 countries and territories, with over $95 \%$ of human deaths occurring in Asia and Africa regions. Every year, more than 29million people worldwide receive a post-bite vaccination. This is estimated to prevent hundreds of thousands of rabies deaths annually. Rabies is one of the neglected tropical diseases that predominantly affects poor and vulnerable populations who live in remote rural locations. Although effective human vaccines and immunoglobulin exist for rabies, they are not readily available or accessible to those in need .Globally, rabies deaths are rarely reported and children between the ages of 5-14 years are frequent victims represent $40 \%$ of people bitten by suspected rabid animals (Joseph, 2019). Rabies is viral infection present in saliva of rabid animals. The incubation period for rabies is typically 2-3 months but may vary from 1 week to 1 year, dependent upon factors such as the location of virus entry and viral load There are two forms of the disease: people with furious rabies exhibit signs of hyperactivity, excitable behavior, hydrophobia (fear of water) and sometimes aerophobia (fear of drafts or fresh air). Death occurs after a few days due to cardio-respiratory arrest (Khalaf, 2018).

Mothers play an important role regarding increasing awareness about rabies and preventive measure, because mothers are half of society, they represent the mother, the wife and the daughter. So, mothers play many roles in society. They are the major coordinators of care and the link to the health care system for their families. Mothers play the key role in coordinating and ensuring access to health care for their children. These women often care for their families while maintaining employment commitments (Marwan, 2019).

Community health nurse plays an important role regarding increasing awareness about rabies and its preventive measure according to three level of prevention. The aim of primary level of prevention is health promotion and specific protection through health education to the women about rabies. Secondary level of prevention is concerned with early detection of rabies and early treatment through washing of the wound under way water and soap and giving the vaccination. Tertiary level of prevention it is concerned with disability and rehabilitation through isolating of the patient in darken room and providing a quiet environment (Gebeyaw \& Teshome, 2016).

\section{Significance of the study}

Whereas, the number of people with vaccinated dog vaccine is (26314) for Qalyubiya Governorate in 2018.In Egypt, people experience many animal bites annually with more than 200000 animals, bites recorded each year mostly from dogs. On average 60 people die annually from rabies in Egypt. (WHO, 2018). Health educational program should be developed and implemented for mothers about rabies to educate them with the most current information and attitude about the disease and its preventive measures

\section{Aim of the study}

This study aimed to assess knowledge and attitude of mothers regarding rabies and its preventive measures. 


\section{Research question}

-What is the mothers' knowledge about rabies and its preventive measures?

- What is the mothers' attitude regarding Rabies and it preventive measures?

- What is the relation between sociodemographic characteristics of the studied women and their knowledge and attitude regarding rabies?

\section{Subjects and Method}

\section{Research design:}

A descriptive cross sectional research design was utilized to conduct the study.

\section{Setting:}

The study was conducted at Maternal and Child Health Center (B) at Benha City.

\section{Sampling: -}

Simple random sample was used in this study. The number of mothers attending to the previously mentioned setting was (3802) over the year of 2019. According to the equation $\left(\mathrm{n}=\mathrm{N} \frac{N}{1+N(e)^{2}}\right)$, the total number was calculated to be (360).

\section{Tools of data collection:}

One tool was used for collecting data, a structured interviewing questionnaire.

\section{A- A structured interviewing} questionnaire: the investigator designed questionnaire based on literature review, and it was written in simple clear Arabic language. It consisted of the following three parts:
Part I: To assess socio-demographic characteristics of the studied mothers: It consists of six questions related to, age, educational level, occupation, residence, family income, and family size.

Part II: To assess the studied mothers' knowledge regarding to rabies which included eight questions in 2 parts ; the first part included 30 items about general information regarding rabies e.g; meaning of rabies, modes of transmission, rabies infects, animal can transmit rabies, signs and symptoms of rabies among human and animals, complication, preventive methods and control. The second part included 7 items about preventive methods and control of rabies.

Scoring system: A score for each answer on questions of knowledge was given as follows: $2=$ If answered yes, $1=$ If answered no, $0=$ don't know.

The knowledge was considered good if the score of the total knowledge equals > $75 \%$ (14), average if the percentage of total knowledge is $50-75 \%(9-14)$ and considered poor if it is less than $50 \%(<9)$.

Part III: It was designed to assess the mothers' attitudes toward rabies, which included twelve questions.

- Scoring system: A score for each answer on questions of attitude was given as follow: 2=Always attitude. $1=$ Indifferent attitude

$0=$ rarely attitude.

Total score of attitude $=24$. The attitude was considered positive if the score of total attitudes is $>75 \%(>18)$, considered 


\section{Knowledge and Attitude of Mothers Regarding Rabies and its Preventive Measure}

indifferent if it equals 50-75\% (12-18) and negative if it is $<50 \%(<12)$.

\section{Ethical considerations:}

Oral consent was obtained from each mothers before conducting the interview and given a brief orientation to the purpose of the study. They were also reassured that all information gathered would be confidential and used only for the purpose of the study. No names were required on the forms to ensure anonymity and confidentiality.

\section{Pilot study:}

A pilot study was conducted to assess tools clarity and applicability. It has also served in estimating the time needed for filling the tool of the study.

It represented $10 \%$ of the sample (38 mothers) they were excluded from the study sample.

\section{Content validity and reliability:}

Tools of the study were given to a group of 5 members of Nursing Faculties Staff from the Community Health Nursing Specialty who reviewed the tools for clarity, relevance, comprehensiveness, applicability and easiness for implementation and according to their opinion minor modifications were carried out. The reliability of the developed tools was estimated using Cronbach's $\alpha$ test to measure the internal consistency of the tools. It was found that the reliability of knowledge was 0.76 , reliability of attitude was 0.61 .

\section{Field work:}

Data were collected throughout the period from beginning of June 2020 to the end of November 2020 a period of 6 months. The investigator visited the selected maternal and child health center (B) from 9 am to $1 \mathrm{pm}$, three days per week by rotation. The fieldwork was performed in the following sequence, study aim and importance was clarified to the studied mothers to gain their support and cooperation,

Questionnaire sheets were distributed to mothers, and they were asked to fill them individually.

\section{Statistical design}

Data were analyzed using the statistical software package for social science (SPSS) version 26. Qualitative data were expressed as numbers and percentages. Chi-square test $\left(\mathrm{X}^{2}\right)$ was used to examine the relation between qualitative variables. Pearson correlation (r) was used to detect associations between quantitative variables.

\section{Significant levels were considered as follows:}

$$
\begin{array}{lll}
\mathrm{P} & <0.05 & \text { significant } \\
\mathrm{P} & >0.05 & \text { not significant } \\
\mathrm{P} & <0.001 & \text { highly significant }
\end{array}
$$

\section{Results:}

Table (1): Shows that; $41.4 \%$ of the studied mothers aged from 40 years with mean \pm SD $(32.96 \pm 7.88), 41.7 \%$ of them were secondary educational level, $70.6 \%$ of them were not work, $59.4 \%$ of them were living in urban area, $63.3 \%$ of them were enough family income and $58.9 \%$ of them were $4-6$ family size. 
Figure (1): Shows that; $93.1 \%$ of the studied mothers had poor total knowledge score regarding rabies; while $4.2 \%$ of them had good total knowledge score and $2.7 \%$ of them had average knowledge score.

Figure (2): Shows that; $57.5 \%$ of the studied mothers had indifferent total attitude score regarding rabies, while $28.3 \%$ of them had positive total attitude score regarding rabies and $14.2 \%$ of them had negative total attitude score regarding rabies.

Table (2): Shows that; there were a highly statistically significant relation between socio demographic characteristics of the studied mothers and knowledge regarding rabies $(\mathrm{p}<0.001)$.

Table (3): Shows that; there were not statistically significant relations between the studied mothers' attitude regarding rabies and their socio demographic characteristics (age, educational level, occupation, residence, family income and family size $)(\mathrm{p}>0.05)$.

Table (4): Shows that; there was a high statistically significant correlation between total knowledge and attitudes of the studied mothers related to rabies and its preventive measures $(\mathrm{P}<0.001)$.

Table (1): Distribution of the studied mothers regarding their socio-demographic characteristics $(\mathbf{n}=360)$.

\begin{tabular}{||c|c|c|}
\hline Socio-demographic characteristics & No & $\%$ \\
\hline Age / years : & 21 & 5.8 \\
<20 & 98 & 27.2 \\
$20-$ & 92 & 25.6 \\
$30-$ & 149 & 41.4 \\
$40-\quad$ X \pm SD= & $32.96 \pm 7.88$ \\
\hline Educational Level: & 111 & 30.8 \\
Basic education & 150 & 41.7 \\
Secondary & 99 & 27.5 \\
University & & \\
Occupation: & 106 & 29.4 \\
Working & 254 & 70.6 \\
Not working & & \\
Residence & 146 & 40.6 \\
Rural & 214 & 59.4 \\
Urban & & \\
Family income: & 43 & 11.9 \\
Enough and saving & 228 & 63.3 \\
Enough & 89 & 24.7 \\
Insufficient & & \\
\hline Family size: & 95 & 26.4 \\
< 4 & 53 & 58.9 \\
4 -6 & & \\
>6 & & 14.7 \\
\hline
\end{tabular}




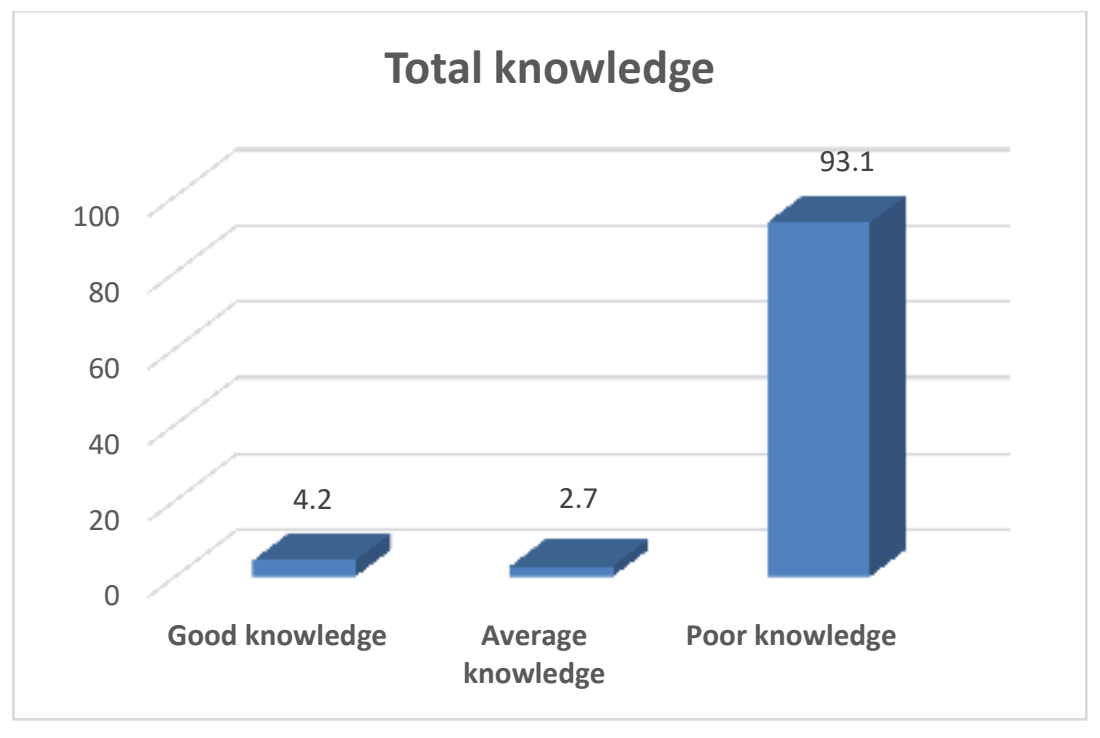

Figure (1): Percentage distribution of the mothers' total knowledge score regarding rabies $(n=$ 360)

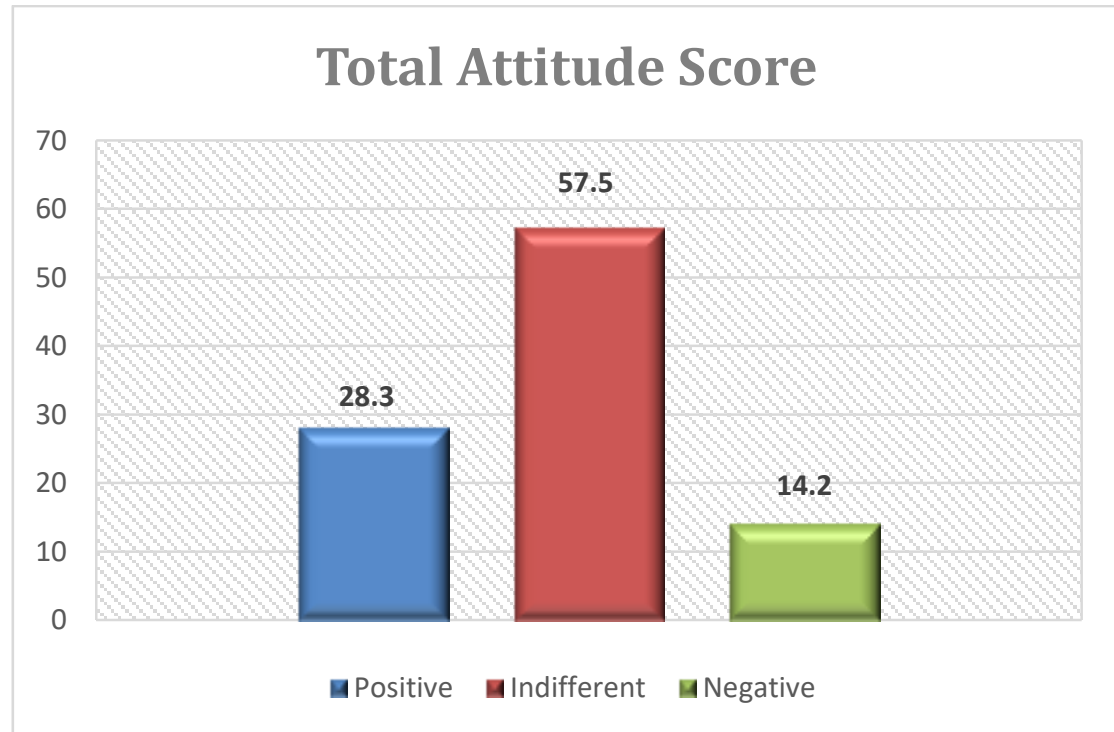

Figure (2): Percentage distribution of the mothers' total attitude score regarding rabies $(n=360)$ 
Table (2): Relation between the studied mothers knowledge \& their socio-demographic characteristic, $(n=360)$.

\begin{tabular}{|c|c|c|c|c|c|c|c|c|}
\hline \multirow{2}{*}{$\begin{array}{l}\text { Socio-demographic } \\
\text { characteristics }\end{array}$} & \multicolumn{2}{|c|}{$\begin{array}{c}\text { Good } \\
(15)\end{array}$} & \multicolumn{2}{|c|}{$\begin{array}{c}\text { Average } \\
(10)\end{array}$} & \multicolumn{2}{|c|}{$\begin{array}{l}\text { Poor } \\
(335)\end{array}$} & \multicolumn{2}{|c|}{ Chi- Square } \\
\hline & No & $\%$ & No & $\%$ & No & $\%$ & $\mathbf{X}^{2}$ & P-value \\
\hline $\begin{array}{l}\text { *Age / years : } \\
<20 \\
20- \\
30- \\
40-\end{array}$ & $\begin{array}{l}9 \\
6 \\
0 \\
0\end{array}$ & $\begin{array}{c}42.9 \\
6.1 \\
0.0 \\
0.0\end{array}$ & $\begin{array}{c}0 \\
0.0 \\
3 \\
7\end{array}$ & $\begin{array}{c}0.0 \\
00.0 \\
3.3 \\
4.7\end{array}$ & $\begin{array}{c}12 \\
92 \\
89 \\
142\end{array}$ & $\begin{array}{l}57.1 \\
93.9 \\
96.7 \\
95.3\end{array}$ & 58.49 & 0.000 \\
\hline $\begin{array}{l}\text { *Educational Level: } \\
\text { Basic education } \\
\text { Secondary } \\
\text { University }\end{array}$ & $\begin{array}{c}0 \\
0 \\
15\end{array}$ & $\begin{array}{c}0.0 \\
0.0 \\
15.2\end{array}$ & $\begin{array}{l}3 \\
7 \\
0\end{array}$ & $\begin{array}{l}2.7 \\
4.7 \\
0.0\end{array}$ & $\begin{array}{r}108 \\
143 \\
84\end{array}$ & $\begin{array}{l}97.3 \\
95.3 \\
84.8\end{array}$ & 46.861 & 0.000 \\
\hline $\begin{array}{l}\text { *Occupation: } \\
\text { Employed } \\
\text { Not working }\end{array}$ & $\begin{array}{c}15 \\
0\end{array}$ & $\begin{array}{c}14.2 \\
0.0\end{array}$ & $\begin{array}{l}4 \\
6\end{array}$ & $\begin{array}{l}3.8 \\
2.4\end{array}$ & $\begin{array}{c}87 \\
248\end{array}$ & $\begin{array}{l}82.1 \\
97.6\end{array}$ & 39.181 & 0.000 \\
\hline $\begin{array}{l}\text { Residence } \\
\text { Rural } \\
\text { Urban } \\
\end{array}$ & $\begin{array}{c}15 \\
1 \\
\end{array}$ & $\begin{array}{c}10.3 \\
0.3 \\
\end{array}$ & $\begin{array}{l}3 \\
7 \\
\end{array}$ & $\begin{array}{l}2.1 \\
3.3 \\
\end{array}$ & $\begin{array}{l}127 \\
207 \\
\end{array}$ & $\begin{array}{l}87.6 \\
96.7 \\
\end{array}$ & 28.589 & 0.000 \\
\hline $\begin{array}{l}\text { *Family income: } \\
\text { Enough and saving } \\
\text { Enough } \\
\text { Insufficient }\end{array}$ & $\begin{array}{c}0 \\
0 \\
0 \\
15\end{array}$ & $\begin{array}{c}0.0 \\
\\
0.0 \\
16.9\end{array}$ & $\begin{array}{l}4 \\
6 \\
0\end{array}$ & $\begin{array}{l}9.3 \\
2.6 \\
0.0\end{array}$ & $\begin{array}{c}39 \\
\\
222 \\
74\end{array}$ & $\begin{array}{l}90.7 \\
97.4 \\
83.1\end{array}$ & 52.393 & 0.000 \\
\hline $\begin{array}{c}\text { * Family size: } \\
<4 \\
4-6 \\
>6\end{array}$ & $\begin{array}{c}3 \\
0 \\
12\end{array}$ & $\begin{array}{c}3.2 \\
0.0 \\
22.6\end{array}$ & $\begin{array}{l}0 \\
6 \\
4\end{array}$ & $\begin{array}{l}0.0 \\
2.8 \\
7.5\end{array}$ & $\begin{array}{c}92 \\
206 \\
37\end{array}$ & $\begin{array}{l}96.8 \\
97.2 \\
69.8\end{array}$ & 51.077 & 0.000 \\
\hline
\end{tabular}


Table (3): Relation between the studied mothers' attitudes regarding rabies \& their sociodemographic characteristics (age, educational level, occupation, residence, family income and family size) $(\mathrm{n}=360)$.

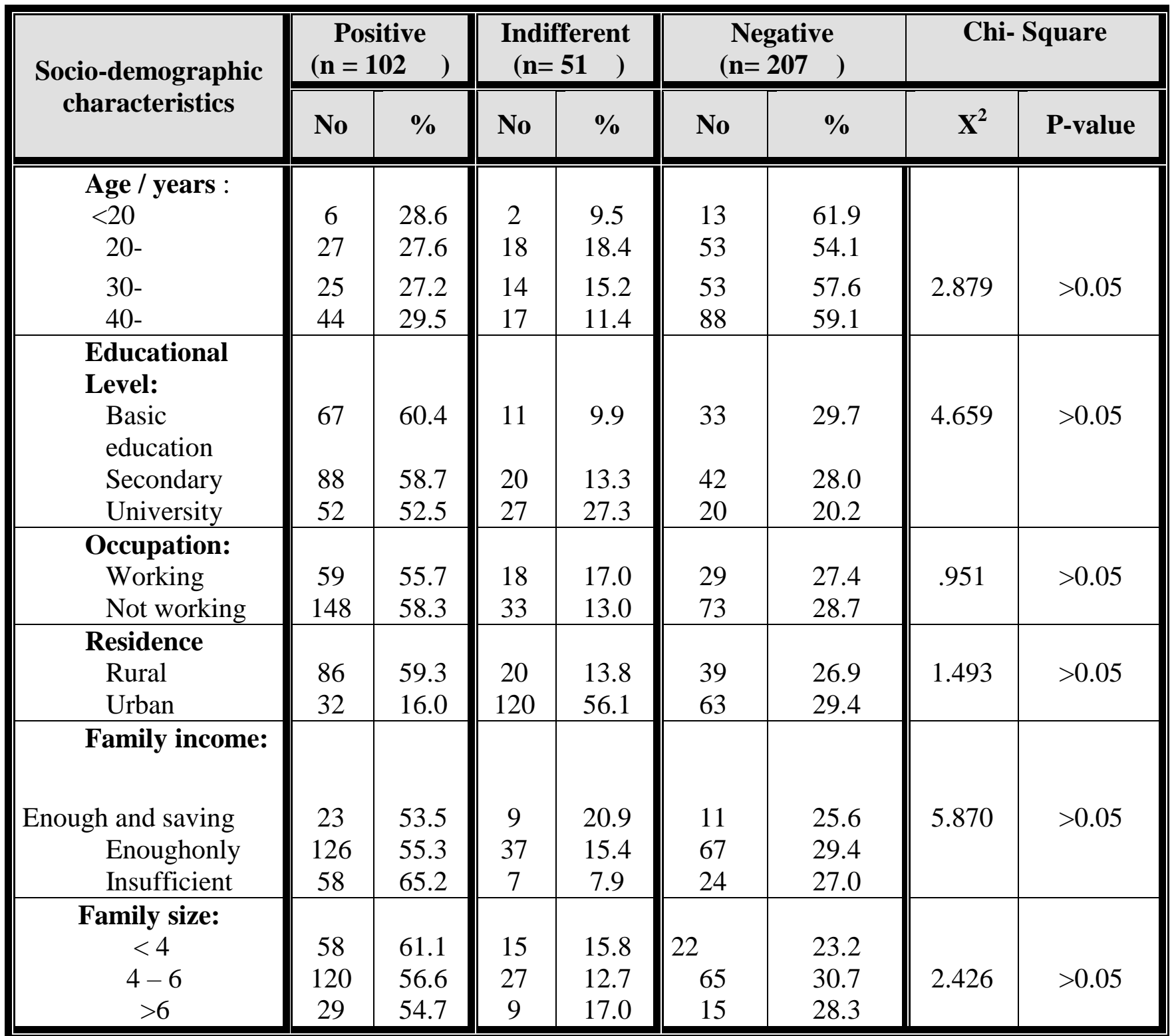

Table (4): Correlation between the mothers' total knowledge and attitudes scores related to rabies, $(n=360)$.

\begin{tabular}{||l|c|c|}
\hline \multirow{2}{*}{ Parameter } & \multicolumn{2}{|c|}{ Total Knowledge } \\
\cline { 2 - 3 } & $\mathbf{r}$ & $\mathbf{P}$ \\
\hline \hline Total Attitudes & 0.04 & $*<0.001$ \\
\hline
\end{tabular}




\section{Discussion}

Rabies is a fatal but preventable viral disease. It can spread to people and pets if they are bitten or scratched by a rabid animal. In the United States, rabies is mostly found in wild animals like bats, raccoons, skunks, and foxes. However, in many other countries dogs still carry rabies, and most rabies deaths in people around the world are caused by dog bites. The rabies virus infects the central nervous system. If a person does not receive the appropriate medical care after a potential rabies exposure, the virus can cause disease in the brain, ultimately resulting in death. Rabies can be prevented by vaccinating pets, staying away from wildlife, and seeking medical care after potential exposures before symptoms start (CDC, 2020).

This study aimed to assess knowledge and attitude of mothers regarding rabies and its preventive measures.

Regarding socio demographic characteristics of the studied mothers, this study showed that; around approximately two fifths of mothers' age was 40 years and more with a mean age $32.96 \pm 7.88$.

This result agrees with Khalaf (2018), who conducted a study on "Health education program regarding rabies knowledge for households in rural areas, assiut governorate" in Egypt and mentioned that $36.2 \%$ of the total sample was 40-50years old.

As regards mothers' educational level; the study showed that; around approximately two fifths of them had secondary educational level. This might be due to decreased number of universities in rural areas. This result agrees with Khalaf (2018), who mentioned that $42.2 \%$ of the participants had a secondary level of education. This finding disagreed with Begum \& Jayanthi (2018), who conducted a study on" Dissertation on A Study To Assess The Effectiveness of Structured Teaching Programme on Knowledge of Mothers Regarding Management of Dog Bite and Prevention of Rabies Among Children Undergoing Treatment in the Anti-Rabies Vaccine Out Patient Department At Institute Of Child Health And Hospital For Children, Egmore, ChennaI. They mentioned that; $26.7 \%$ of mothers had secondary educational level. Also this study disagreed with Bihon et al (2020) who studied" Rabies: Knowledge, Attitude and Practices in and Around South Gondar, North West Ethiopia" and mentioned that; $15.1 \%$ of studied sample had secondary educational level.

Regarding to income of the mothers, the present study revealed that; more than three fifths of the studied mothers had enough income. These findings disagree with Khalaf (2018), who mentioned that; $48.2 \%$ were falling in the middle-level social class.

According to the studied mother's family size, the present study illustrated that; slightly less than three fifths of them had $4-6$ family members. This might be due to that the majority of the studied mothers are living in shared houses and extended families. This result agrees with Bihon et al (2020) who mentioned that; $50.3 \%$ Family size was $4-6$ family members.

According to mothers' knowledge about signs and symptoms of rabies among humans, this study results showed that; the majority of mothers did not know the signs and symptoms 
of rabies among rabid humans. These results are inconsistent with Joice et al (2016) who conducted a study on "Knowledge, Attitude and Practices Regarding Dog Bite and its Management among Adults "in Rural Tamil Nadu and mentioned that; $12.7 \%$ of adults did not know signs and symptoms of rabies among rabid humans. This might be due to is because of the lack of knowledge that the vaccination of animals is the first way to prevent rabies

Concerning of the mothers total knowledge score regarding rabies, this study results showed that; most of the studied mothers had poor knowledge score regarding rabies. This finding agreed with Begum \& Jayanthi (2018), they found that; $10.13 \%$ of the studied mothers had good knowledge score regarding rabies. This might be due to low level of education and housewife's mothers had a negative effect on mothers' ability to acquire knowledge well.

Regarding to mothers attitude regarding rabies, this study results showed that; slightly less than three fifths of the studied mothers had indifferent total attitude score regarding rabies, This finding was in agreement with Davlin et al (2016) who conducted a study on" Knowledge, attitudes and practices regarding rabies in Filipions following implementation of the Bohol Rabies Prevention and Elimination Programme" in Filipions. They mentioned that; $54.1 \%$ of the studied mothers had indifferent total attitude score regarding rabies. This might be due to the most of the studied mothers had feel that the disease is dangerous and worthy of all fear.

According to relation between the studied group knowledge \& their sociodemographic characteristic, the present study revealed that; there were a highly statistically significant relations between demographic characteristics of the studied mothers and their age, educational level, occupation and family income and family size $(\mathrm{p}<0.001)$. These results were in the same line with Sivagurunathan et al (2021) who reported that; there were highly statistically significant relations between demographic characteristics of the studied mothers and their age, educational level, occupation, family income and family size in their study on " Knowledge, attitude, and practice study on animal bite, rabies, and its prevention in an urban community" in India

According to relation between the studied mothers attitudes regarding rabies \& their socio- demographic characteristics, the present study revealed that; there were not significant relationship between the studied mothers' attitude and their socio demographic characteristics (age, educational level, occupation, residence, family income and family size $)(p>0.05)$. These results were in the same line with Tandon et al (2017) who reported that; there were not significant relations between the studied mothers' attitude and their socio demographic characteristics (age, educational level, occupation, residence, family income and family size) $(\mathrm{p}>0.05)$ in their study on "A Community Based Survey on Rabies Control and Prevention using KAP in Jammu", India.

\section{Conclusion:}

Most of the studied mothers had poor knowledge score about rabies. While slightly less than three fifths of them had indifferent total attitude score regarding rabies. Also, there 
were a statistically significant relation between socio demographic characteristics of the studied mothers and knowledge regarding rabies. There were no statistically significant relations between the studied mothers attitude regarding rabies and there socio demographic characteristics (age, educational level, occupation, residence, family income and family size). However, there was highly statistically significant correlation between total knowledge scores and attitudes of the studied mothers related to rabies.

\section{Recommendations:}

1- Health educational program should be developed and implemented for mothers to educate them about rabies with the most current information and practices about the disease.

2- Booklets should be available and distributed to all mothers about the disease and health-related practices.

3- All possible forms of mass media such as T.V., Radio, and posters are needed to help in disseminating information about rabies.

\section{References}

Begum T., \& Jayanthi R. (2018).Dissertation on astudy to assess the effectiveness of structured teaching programme ofmothers regarding management of dog bite and prevention of rabies among children undergoing treatment in the anti- rabies vaccine outpatient department at institute of child health and hospital for children ,egmore, Chennai-8 M.sc(nursing)degree examination branch-II child health nursing college of nursing madras medical college,CHENNAI-600 003, available at:

http://repositorytnmgrmu.ac.in/11616/1/300216 318priyadarshini.pdf

Bihon A., MeresaD., and Tesfaw A. (2020).Rabies: Knowledge, Attitude and Practices in and Around South Gondar, North West Ethiopia" available at: https://www.ncbi.nlm.nih.gov/pmc/articles/PM C7151027/

Centers for Disease Control and Prevention (CDC,2020). Animals and Rabies, available at:https://www.cdc.gov/rabies/animals/index.ht $\mathrm{ml}$. Accessed on 12-1-2021 at 2.00p.m

Davlin L., Lapiz M., Miranda E., and MurraY. (2016) : Knowledge, attitudes and practices regarding rabies in Filipions following implementation of the Bohol Rabies Prevention and Elimination Programme" in in Filipions Published:20 December 2017https://doi.org/10.1098/rspb.2017.1880.

Hossain M., Ahmed K., Bulbul T., Hossain S., and Rahman A. (2018). Human rabies in rural Bangladesh. Epidemiology Infect 140: 1964-1971.

Joice Y., Singh Z. , Datta S.(2016). KnowledgeAttitude and Practices Regarding Dog Bite and its Management Among Adults "in Rural Tamil Nadu, available at https://www.researchgate.net/profile/Shib-

Sekhar-

Datta/publication/308611826_Knowledge_Attit ude_and_Practices_Regarding_Dog_Bite_and_i ts_Management_Among_Adults_in_Rural_Ta mil_Nadu/links/57e8c55108aedcd5d1ac6ad6/K nowledge-Attitude-and-Practices-RegardingDog-Bite-and-its-Management-Among-Adultsin-Rural-Tamil-Nadu.pdf. 
Joseph E. (2019). Rabies, available at: https://kidshealth.org/en/parents/rabies.html

Khalaf F,and Khalaf S. (2018). Health

Education Program Regarding Rabies

Knowledge for Households in Rural Areas, Assiut Governorate, Egypt. International Journal of Nursing Research (IJNR)2018;4(1):13-22.

Marwan, M. ( 2019 ).The Role of The Women in The Development of Society. Available at:https://www.yourarticlelibrary.com.

Accessed on 18 January/ 2020.

Sivagurunathan C., Umadevi R., Balaji A., Rama R., Gopalakrishnan S .(2021) : Knowledge, attitude, and practice study on animal bite, rabies, and its prevention in an urban community" in India available at https://www.researchgate.net/publication/34965 2630_Knowledge_attitude_and_practice_study _on_animal_bite_rabies_and_its_prevention_in _an_urban_community.

Tandon S., Kotwal S., Malik M., Singh M., Kumar D., Shafiq M., and Kumar M(2017). A Community Based Survey on Rabies Control and Prevention using KAP in Jammu, India" available at

https://www.researchgate.net/profile/Dinesh-

Kumar-

34/publication/325416041_A_Community_Bas ed_Survey_on_Rabies_Control_and_Preventio n_using_KAP_in_Jammu_India/links/5b0cfec6 0f7e9b1ed7fbd2fb/A-Community-Based-

Survey-on-Rabies-Control-and-Preventionusing-KAP-in-Jammu-India.pdf

World Health Organization( WHO, 2018). who conducted a study on "Driving progress towards rabies elimination $2^{\text {nd }}$ international meeting of the -African Rabies control Network(PARCON).8, ISSN 0512-3054. 


\section{معلومات واتجاهات الامهات عن داء الكلب وطرق الوقايه منه}

\section{نوراجميل أحمدالخولى- هاله مصطفي الهادى هاثم- أمينة عبد الرازق محمود}

داء الكلب هو أحد أمر اض المناطق المدارية المهمله التى تصيب فى الغالب السكان الفقراء والضعفاء الذين يعيشون فى المناطق الريفيه النائيه. لذلك هدفت هذه الدراسة إلى تقييم معلومات وأتجاهات الامهات عن داء الكلب وطرق الوقايه منه. وقد أجريت الدراسة في مركز صحة الام والطفل الموجود بجوار مسنشفي حميات بنها بمدينة بنها. حيث تم إستخدام عينه عشو ائيه بسيطه فى هذه الدراسه على. بس سيده. و أسفرت نتائج هذه الدر اسة على وجود علاقة ذات دلالة إحصائية بين معلومات و إتجاهات الامهات نحو داء الكلب. وأوصت الدر اسة بوضع وتطبيق برنامج تثقيفي صحى لتحسين معلومات و اتجاهات الأمهات عن مرض داء الكلب. 